\title{
Private Car, Public Oversight: Municipal Regulation of Ride-hailing Platforms in Toronto and the Greater Golden Horseshoe
}

\author{
Jonathan Woodside $^{\mathrm{a}}$ (D), Markus Moos ${ }^{\mathrm{a}}$ (D), and Tara Vinodrai ${ }^{\mathrm{b}}$ iD \\ ${ }^{\text {a }}$ School of Planning, University of Waterloo \\ ${ }^{\mathrm{b}}$ Institute for Management and Innovation and Graduate Department of Geography and Planning, \\ University of Toronto
}

\begin{abstract}
Résumé
Les municipalités de nombreuses régions du Canada ont réglementé les services de location de véhicules. Avec le development des plateformes de covoiturage, telles que Uber et Lyft, cette responsabilité de produire un service fiable a été largement transférée aux plateformes privées. À l'aide d'une étude de cas de la ville de Toronto et de la région du Golden Horseshoe, cet article examine comment la réglementation locale a changé dans ce service de mobilité urbaine essentiel. S'appuyant sur une analyse de 27 entretiens avec des employés municipaux, des conseillers et des experts du secteur, une revue des médias locaux écrits et un examen des documents gouvernementaux, l'étude constate que les municipalités se retirent du contrôle direct du secteur en raison d'un manque d'outils de surveillance et de la priorité accordée au secteur privé sur le service public. L'étude conclut en examinant les défis actuels qui peuvent être relevés par une plus grande surveillance du service.
\end{abstract}

Mots-clés: économie de plateforme, covoiturage, réglementation municipale, planification des transports locaux

\section{Abstract}

Municipalities in many regions of Canada have regulated vehicle-for-hire services. With the rise of ridehailing platforms, such as Uber and Lyft, the responsibility to produce a reliable vehicle-for-hire service has largely been transferred to private platforms. Using a case study of the City of Toronto and the Greater Golden Horseshoe, this article examines how local regulation of urban mobility service has changed. Drawing upon an analysis of 27 interviews with municipal staff, councillors, and industry experts, a review of written local media, and a review of government documents, the study finds that municipalities are withdrawing from direct control of the industry due to a lack of tools of oversight and a prioritization of private industry over public service. The study concludes by discussing ongoing challenges that may be addressed by greater oversight of the service.

Keywords: platform economy, ridesharing, municipal regulation, local transportation planning

Canadian Planning and Policy / Aménagement et politique au Canada, Volume 2021, pages 146-165.

This work is licensed under a Creative Commons Attribution 4.0 International License.

ISSN 2562-122X

DOI 10.24908/cpp-apc.v2021i01.14362

CIP-ICU \& ACUPP-APUCU 


\section{INTRODUCTION}

The emergence of ride-hailing services such as Uber and Lyft and the resulting changes to transportation systems have intensified calls to relax existing regulations in the vehicle-for-hire industry, including taxis and limousines, while also sparking demand for new regulation to address its potential impacts. Although prior studies have documented regulatory change at a national scale or in major cities (Brail, 2018; Chen et al., 2015; Dubal, 2017; Kim \& Hwang, 2019; Puche, 2019; Spicer et al., 2019), none have provided a systematic survey of this transformed regulatory landscape at the municipal scale across an entire region. This paper provides an analysis of municipal ride-hailing legislation in the Greater Golden Horseshoe including and surrounding Toronto. The aim is to understand how municipalities conceive of their roles as regulators of vehicle-for-hire services and how that has developed after the emergence of ridehailing platforms.

The vehicle-for-hire industry plays an important role in most communities' transportation systems by providing door-to-door, on-demand services to residents (Ellis, 2016; King \& Saldarriaga, 2017). Municipalities have long regulated privatelyoperated, for-hire vehicles to protect the public interest (Cooper et al., 2010). Historically, the aim of regulation has been to facilitate efficient operation of the vehicle-for-hire industry while also protecting residents by requiring standards of quality and pricing (Dempsey, 1996). To achieve these goals, municipalities have typically employed what has become known as the QQE approach that places limits on the quantity of licensed drivers, standards on the quality of the car and driver, and economic controls on fares (Cooper et al., 2010). However, the QQE approach is criticized by those who argue that such regulations have been co-opted by industry insiders and/or are poorly enforced, resulting in inefficiencies and poor service (Blasi \& Leavitt, 2006; Mitchell \& Koopman, 2019; Papillon, 1982).

Platforms are now applied to industries across the economy, opening up new forms of innovation in the service economy (Kenney \& Zysman, 2016). The application of platforms to local service industries like the vehicle-for-hire industry has remade the business model for these industries, placing data at the centre of the service and creating new and unpredictable relationships between investors, platform firms, consumers and service providers (Srnicek, 2017). As such, platforms have opened local services up as a new frontier for global capital (Kenney \& Zysman, 2016). In the vehiclefor-hire industry, platforms provide a digital network infrastructure to match passengers with drivers and facilitate digital payments (Sundararajan, 2016). It is argued that through these digital tools platforms create an efficient and programmable market structure where time consuming and expensive managerial forms of government were once necessary (Harding et al., 2016). These platforms create a new layer of private infrastructure in the ride-hailing industry that promises to settle operational inefficiencies without the need for municipal intervention (Harding et al., 2016).

As these platforms have expanded, they have provided a layer of infrastructure in the for-hire vehicle industry that challenges the authority and capacity of municipal regulators. Some scholars praise platforms for this disruption. They argue platforms lower transaction costs for business and open up new market opportunities (Lobel, 2019; Sundararajan, 2017). These platforms also disrupt barriers to market entry previously established under the QQE approach in that they permit a new class of casual drivers operating as private individuals. Because of the perceived efficiencies (and arguably consumer demand), many municipal regulators quickly revised regulations to be more permissive of ride-hailing platform activities (Collier et al., 2018). In some cases in the United States, deregulation was led at the state level, with municipal regulation pre-empted by changes in state law (Collier et al., 2018). Elsewhere, in both state and municipal governments, there has been a consistent push toward platform self-regulation in the industry (Collier et al., 2018). However, this changing regulatory regime does not mean that 


\section{Municipal regulation of ride-hailing platforms in Toronto and the Greater Golden Horseshoe}

there are fewer burdens upon those drivers who actually deliver the service. Instead this study finds that the practices common to past industry regulations remain, but have been transferred to the platform, with only limited public oversight.

Despite the new regime, researchers have identified numerous policy concerns such as traffic congestion, poor working conditions, and market concentration where industry self-interest aligns poorly with public goals (Clewlow \& Mishra, 2017; Collier et al., 2018; Dubal, 2017; Rosenblat, 2018). Further, these regulatory changes can have effects on communities that go well beyond the industry itself. For instance, Ferreri and Sanyal (2018) argue that ride-hailing platforms contribute to cementing private interests into urban governance under neoliberalism. The digital ride-hailing services introduce and reinforce new social and technical patterns of cost and convenience that influence how cities agglomerate and deliver services - features that some theorists describe as "the basic glue that holds the city together" (Ferreri \& Sanyal, 2018; Graham \& Marvin, 2001; Scott \& Storper, 2015, p. $6)$. In other words, digital platforms may help install a particular politics into the fabric of communities, increasingly oriented to private market ideals and away from public ones.

What remains less known is how this new private and corporate form of regulatory oversight has been conceived and developed in practice. In this study, we thus ask how municipalities conceive of vehiclefor-hire regulation and how they have developed regulatory intervention in digital ride-hailing platforms. We examine these questions through a case study of the City of Toronto and the surrounding municipalities of the Greater Golden Horseshoe (GGH), where urban and suburban municipal governments actually intervened (as of 2018). We study the characteristics of what we might call a new regulatory regime (and its justification) through an analysis of key stakeholder interviews and government documents. The findings suggest that increasing government oversight of ride-hailing platforms would likely benefit residents, but that there are significant barriers to implementation. These barriers include a lack of tools to expand this oversight over novel industry structures like platform software and algorithms as well as a paradigm among municipal staff and council members that vehicle-for-hire services are, in essence, private-sector industries that require freedom from regulation. We argue that this results in a governing regime that does not provide the oversight necessary to preserve the interests of local residents or the drivers. We conclude that, in order to protect local interests, municipalities must build capacity to oversee local ride-hailing services. A large part of this is to fully recognize the existing authority that is invested in municipalities to regulate the industry and to expand cooperation with other levels of government where there are limits to municipal powers.

\section{The Ride-Hailing Platform under Municipal Regulation}

The capacity of platforms to network buyers and sellers of local services has produced systems that are easier to navigate leading to the entry of new market actors across a range of services from shortterm rentals to household tasks and for-hire vehicles. Ride-hailing platforms have emerged as a significant development in the governance of vehicle-for-hire industry. After a period of institutional experimentation where platforms developed diverse commercial and non-commercial relationships, these platforms have reached an equilibrium dominated by large commercial interests (Geobey, 2017). This development has challenged existing institutions to account for an industrial scale of non-professionals in these industries.

In the United States and Canada, states and provincial legislatures have commonly vested municipalities with regulatory powers over the vehicle-for-hire industry (Cooper et al., 2010; Papillon, 1982). Historically, governments recognized that market imperfections and potential negative externalities require regulatory intervention (Dempsey, 1996). This regulation became common during the 1930s (Cooper et al., 2010). At that time, for-hire-vehicle markets were described as a 


\section{Municipal regulation of ride-hailing platforms in Toronto and the Greater Golden Horseshoe}

declining cost industry where rising competition was leading to rising costs for consumers (Dempsey, 1996).

For instance, the taxi industry completes transactions in isolated cars making it hard for people to compare prices and leverage competitive pressures; the mechanical condition of cars is not well understood by passengers, making them illequipped to ensure their own safety; and low barriers to entry frequently result in market congestion (Dempsey, 1996; Harding et al., 2016). In this context, cars were designated as "public" vehicles, even though they were operated by private companies and individuals, and standards were set to ensure public safety and reasonable fares in order to build trust in the industry (Cooper et al., 2010; Dempsey, 1996). Municipalities have thus followed a trend shared widely within urban social and technical networks to target regulation to operators rather than consumers directly (Dupuy, 2008).

The QQE approach to regulation has been resilient over the years but has also encountered frequent opposition. It is alleged this regulatory approach distorts the vehicle-for-hire market by producing small groups of industry insiders who profit from underinvestment in the industry to the detriment of everyone else (Mitchell \& Koopman, 2019). Movements to deregulate the vehicle-for-hire industry spread throughout the world in the 1980s and 1990s following a growing interest in market governance (Dempsey, 1996). According to Dempsey (1996), the resulting regulatory changes often reverted back to the QQE approach due to poor results including a proliferation of drivers crowded into taxi stands, and higher rates for users as drivers compensate for their long wait times. By 1996, Dempsey finds that all but four of the 21 cities he surveyed had returned to regulate the industry, and that those cities that remained deregulated tended to be small (Dempsey, 1996).

Whether intended or not, the rise of ride-hailing platforms today has resulted in a similar but "more successful" round of regulatory change. Ridehailing platforms challenge the QQE approach where they deny limits to the numbers of drivers and build their operations around the freedom to set fares. However, platforms differ from past changes in important ways. While past deregulatory movements were primarily a "roll back" of municipal regulation, the platform has "rolled out" a new institution whereby market-based principles are prioritized in the organization of the industry (see Hackworth, 2013; Peck \& Tickell, 2002 regarding the roll out and roll back of neoliberal governance). In so doing, the ride-hailing platform does not simply leave an institutional void, but replaces the QQE approach with a system that corresponds to neoliberal theory (Brenner \& Theodore, 2002).

The success of ride-hailing platforms has avoided a repeat of these past cycles of deregulation and reregulation. However, it should be recognized that policy concerns like congestion that accompanied past eras of deregulation remain (Erhardt et al., 2019). Further, the list of policy concerns has been expanded by current scholars to include a growing set of issues (Table 1). Whereas Dempsey (1996) was primarily concerned with the economic instability of the industry, Collier et al. (2018) enumerate a more comprehensive regulatory agenda for the ride-hailing industry that prioritizes questions of safety, consumer protection, competition, worker protection and public goods. Still other scholars identify new policy concerns. Examples include privacy concerns over customer data extraction by platforms, asymmetrical power relationships, and trends within the industry toward monopoly concentration (Calo \& Rosenblat, 2017). Altogether, it can be argued that the maintenance of minimum standards and potential harms of negative externalities warrant ongoing regulatory controls.

Perhaps what is most salient from the list of policy concerns shown in Table 1 is the growing level of uncertainty in the industry. Prices have fallen in the past. But many question if that will continue; and the current context of the COVID-19 pandemic only serve to intensify uncertainty. It has been posited that investments in platform-building are expected to be recouped over time through rising costs for consumers and falling wages for drivers as a result of monopolization of the network (Horan, 2015). 
Table 1. Policy Interests in Regulation of Vehicle-for-hire Industry

\begin{tabular}{|c|c|c|}
\hline Goals of Regulation & Policy Interests & \\
\hline \multirow[t]{5}{*}{ Quality } & \multirow[t]{2}{*}{ Level of service } & $\begin{array}{l}\text { Discriminatory pricing and fare transparency (Bokányi \& Hannák, 2020; Calo \& } \\
\text { Rosenblat, 2016; Chen et al., 2015) }\end{array}$ \\
\hline & & Speed of service (Thebault-Spieker et al., 2018) \\
\hline & \multirow[t]{3}{*}{ Safety } & Condition of vehicle (NYC Taxi \& Limousine Commission, 2018) \\
\hline & & Driver Capability (Rayle et al., 2016) \\
\hline & & Driver \& platform accountability \\
\hline \multirow[t]{11}{*}{ Distribution of benefits } & \multirow{4}{*}{$\begin{array}{l}\text { Consumer } \\
\text { protection }\end{array}$} & Accessibility and non-discrimination (NYPLI, 2018) \\
\hline & & Insurance (Davis, 2015) \\
\hline & & Data ownership and security (Attoh et al., 2019; Calo \& Rosenblat, 2016) \\
\hline & & Permits and Fees (Van den Steenhoven, 2016) \\
\hline & \multirow[t]{2}{*}{ Competition } & Organization of market (Acquier, 2019; Armstrong, 2010; Zale, 2019) \\
\hline & & Risk of monopoly (Harding et al., 2016) \\
\hline & \multirow[t]{5}{*}{ Worker protection } & Driver income (Mishel, 2018; Wells, 2019) \\
\hline & & Worker discipline and dispute settlement (Rosenblat, 2018) \\
\hline & & Worker health (Hua \& Ray, 2017; Reid-Musson et al., 2020) \\
\hline & & Discrimination (Cook et al., 2018; Schoenbaum, 2017) \\
\hline & & Employment status and organization (Dubal, 2017; Johnston, 2018) \\
\hline \multirow[t]{4}{*}{ Public goods } & \multirow{2}{*}{$\begin{array}{l}\text { Transportation } \\
\text { system }\end{array}$} & Traffic congestion (Henao \& Marshall, 2019; Erhardt et al., 2019) \\
\hline & & Transit integration (Clewlow \& Mishra, 2017) \\
\hline & Environment & Pollution (Jalali et al. 2018) \\
\hline & Public finances & Taxation (Viswanathan, 2018) \\
\hline
\end{tabular}

Table adapted from Dempsey, 1996, p. 102; Collier et al., 2018, p. 6.

Indeed, a recent experiment made public by Lyft, demonstrated that the elimination of current subsidies from the platform resulted in an increase in price of $24 \%$ and a decrease of driver earnings of $15 \%$ over a three-day period (Guse, 2019). Furthermore, decreases in pay for drivers might raise new questions regarding service quality and drivers' abilities to earn a livelihood.

\section{New Local Regulatory Challenges}

The rollback of QQE regulations and challenges to finding regulatory answers to policy concerns have been attributed to structural changes to the service as a result of platforms, sometimes referred to as "platformization" (Plantin et al., 2018). Four challenges have been documented in the literature: 1) the changing class of drivers; 2) the changing potential for regulatory capture; 3 ) the scale of the industry and cross-subsidization; and 4) the practical challenges of oversight.

Class of drivers: By creating a tool for organizing casual labour, digital platforms empower a class of drivers that has not typically been targeted by regulation. These are the casual drivers who operate on the platform temporarily or occasionally, on an as-needed basis (Farrell et al., 2018). Previous iterations of vehicle-for-hire regulations regulated drivers as part of an entire industry, and could influence operations by licensing a class of licensed full-time or near full-time drivers and focusing Canadian Planning and Policy 2021 


\section{Municipal regulation of ride-hailing platforms in Toronto and the Greater Golden Horseshoe}

regulations on these professionals that were (arguably) invested with an obligation to the public in their conduct. Casual drivers have typically been barred from the market. With these drivers now included through platforms, their small size and temporary commitment present a challenge to regulators. As Zale (2019) notes, small actors - such as casual drivers - are commonly ignored by industry regulations because they are not always considered large enough to be relevant; small actors operate in private rather than commercial premises; and, small actors are expensive for regulators to reach. Thus, the expansion of the casual workforce makes it more challenging to regulate. It may also raise new issues regarding professionalism and service quality that are more difficult to monitor among a large number of small actors who only engage in service delivery (i.e., driving) on an occasional basis.

Regulatory capture: Critics of municipal regulation over the past century have lamented the likelihood of "regulatory capture" by industry actors in the vehicle-for-hire industry - that is insiders who are able to promote their interests over the public good as a result of relationship building with the regulator (Collier, et al., 2018). Poor conditions of taxis and discourteous service from some drivers were blamed on a regulatory system that was too lax on industry insiders ignoring the wider public good (Mitchell \& Koopman, 2019). Such allegations are likely overstated as taxi firms are small and lack the organizational heft to reward cooperative regulators with contracts after leaving the public service. If ride-hailing platforms were seen as a capturebusting dynamic, scholars today argue that we risk simply transferring capture towards a new political coalition (Collier et al., 2018). With as many as 37 American states having pre-empted municipal regulation in favour of a more lenient form of selfregulation by platforms, critics have argued that new regulations should be attributed to lobbying at the state level of government (Dupuis et al., 2018; Collier et al., 2018). Collier et al. (2018) find that many state regulations for ride-hailing platforms have been written by the platform firms themselves or closely mirror industry promoted policies. As a

CIP-ICU \& ACUPP-APUCU result of these state policies, they find that regulatory capacity for industry oversight has been reduced.

Industry scale and cross-subsidization: The firms that are heavily involved in lobbying include a handful of global businesses that operate in cities across the globe. Even in the past the ride-hailing industry has had some level of cross-subsidization, for instance by homogenizing the level of service across neighbourhoods of different population densities and income levels. But the size of platforms, and the scale at which they operate, brings to bear mechanisms of cross-subsidization that are global in scale (Srnicek, 2017). For example, Uber provides a short description of the variables that inform pricing but provides little detail (Uber, 2021). Critics have noted the company pricing can be opaque and unpredictable (Calo \& Rosenblat, 2017; Chen et al., 2015). Uber's approach to leveraging data collection for discriminatory pricing is commonly known as "route-based pricing." In some jurisdictions, Uber varies rates based on proprietary and undisclosed variables (Newcomer, 2017). While it is uncertain as to the data which is actually informing prices, it appears that ride-hailing platform firms are reducing the direct relationship between price and the cost of service provision (Calo \& Rosenblat, 2017).

Further, where this data is valuable for applications in other industries, from sales and marketing to political organization, platforms have a global market for this local resource (Srnicek, 2017). This gives platforms the ability to supplement driver operations with sales from collected data. It also gives platforms the incentive to subsidize those individuals with valuable data in the marketplace. The scale at which the ride-hailing industry operates and the scale of the market for big data permits a new type of cross-subsidization at the global scale, no longer limited to specific geographic jurisdictions. Cross-subsidization is not a new corporate practice for vehicle-for-hire services but this scale has certainly shifted with dramatic implications for local taxi firms' abilities to compete with global players. 
Practical challenges: There are also new practical challenges to regulation. For instance, Khan (2016) argues that when platforms "implement discriminatory pricing on a wide scale, each individual would be subject to his or her own personal price trajectory, eliminating the notion of a single pricing trend" that could be easily monitored across a jurisdiction using aggregated data (p. 765). Calo and Rosenblat (2017) also note that those who "investigate [platform] firms may need to reverse engineer platforms, scrape data, impersonate consumers, and perform other activities aimed at exploring firm practices" (p. 685). These are capabilities that are not typically available (or at least not resourced adequately) at the municipal level. Further, in this new more market-driven environment, it is not just platforms that may be exercising control over prices for private gains. There is evidence that groups of drivers are also strategizing in ways that undermine the system itself, for instance, by acting collectively on an informal basis to prompt fare increases (Griswold, 2018).

Digital ride-hailing platforms have transformed the vehicle-for-hire industry by leveraging personal data, activating cross-industry and global subsidization, and changing the scale of operations. But changing social and technical components of vehicle-for-hire services have also challenged the authority and capacity of municipal regulation. Without the comprehensive authority and tools of oversight available to municipal actors, this industry is recreated more along private interests in a sector that once resembled a privately-delivered, publicservice. Ultimately this has created an industry with important local effects that is less accountable to the public broadly and has less space to insert public values. Thus, there clearly remain several policy issues that scholars have found to be unresolved by regulators or self-regulated platforms. The liberalization of this industry suggests that there is falling demand for for-hire vehicles to be controlled as they have been in the past. Moreover, this has placed the onus on residents and workers to remobilize over policy concerns in order to see regulatory oversight. Our paper tracks how change to the system of vehicle-for-hire services has been rationalized by municipal regulators to accept this shift from protecting basic transportation services to encouraging private sector innovation focused on higher cost market niches.

\section{Method}

To learn how and why specific municipalities are governing digital ride-hailing platforms, we focus on Toronto and the Greater Golden Horseshoe (GGH). The study examines the perspective of municipal actors and the underlying rationale informing regulations. The analysis includes municipalities in the GGH region that regulated or were considering regulation of ride-hailing platforms as of the fall of 2018. The study draws upon a review of literature on digital platforms, historical accounts of the provision of urban services, the emergence of ride-hailing platforms in particular, and the experience of drivers on those platforms. As part of a larger project examining ride -hailing, it also draws upon other evidence, including interviews with drivers and driver-created video logs.

\section{Local Context}

The Greater Golden Horseshoe (GGH) region surrounds the City of Toronto and stretches across the western shore of Lake Ontario (Figure 1). The GGH region was chosen for this study due to its large number of municipal regulators within a single region. The region has a population of over nine million spread between urban centers as large as the City of Toronto (pop. 2,731,571) and as small as Grand Valley in Dufferin County (pop. 2,956). Though not a distinct legal jurisdiction, the GGH region has been used by the Province of Ontario as an important scale for the governance of processes of urban agglomeration and growth including transportation and land use planning (Ministry of Municipal Affairs and Housing, 2020).

Municipalities in Canada are "creatures of the provinces" and governed via the doctrine of "express authority" (Sancton, 2011, p. 7, 29). In the case of ride-hailing, powers to regulate are granted 


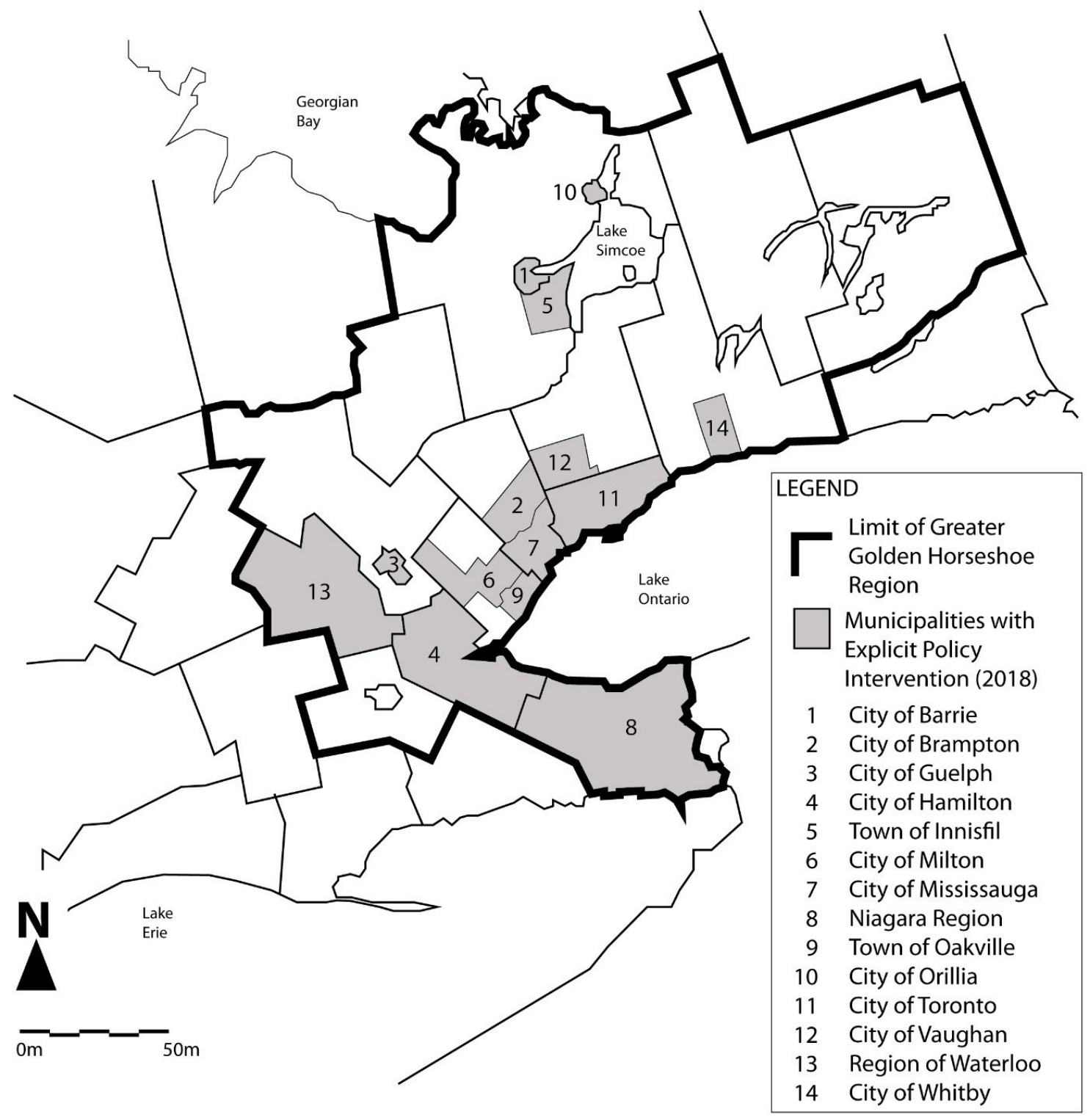

Figure 1. Case Study Municipalities in the Greater Golden Horseshoe

Source: Metrolinx (2016). Further Connecting the Greater Toronto and Hamilton Region: Discussion Paper for the Next Regional Transportation Plan.

to the municipalities via the Municipal Code (2001, Ch. 156) and City of Toronto Act (2006, Ch. 94). In general, vehicle-for-hire services, which typically function on locally owned roads, are generally the responsibility of lower-tier municipalities though upper-tier municipalities, Niagara and Waterloo, are explicitly singled out to regulate the service. These powers are held more or less consistently across the 75 municipal governments in the region, including two aforementioned regional municipalities, 63 lower-tier municipalities as well as ten single-tier municipalities (Association of Municipalities Ontario, 2020; Municipal Code, 2001).

This distribution of authority categorizes the regulation of vehicle-for-hire services like other businesses tied to consumer protection, health and safety, and nuisance control. Yet, the vehicle-forhire industry is also explicitly singled out to provide 
municipalities with broad powers of regulation (City of Toronto Act, 2006; Municipal Code, 2001). These powers, that closely mirror the QQE framework (above), state that municipalities: "May,

a) establish the rates or fares to be charged for the conveyance of property or passengers either wholly within the municipality or from any point in the municipality to any point outside the municipality;

b) provide for the collection of the rates or fares charged for the conveyance;

c) limit the number of taxicabs or any class of them" (Ontario, 2001, 156 (1) a - c).

Of the potential 75 municipalities with regulatory authority over vehicle-for-hire services enumerated above, within the GGH region, 13 developed a program or revised by-laws to regulate ride-hailing platforms at the time of the research project. To date, while the province has shown support for ridehailing platforms by revising the insurance act to enable insurance products for casual drivers, no attempts have been made to pre-empt municipal bylaws with provincial legislation in Ontario. Rather, this case study shows how ready local regulators are to give up their powers. Unlike some other cases (e.g., Austin, Texas), this move to liberalization in Ontario has actually been led by municipal authorities.

\section{Case Study Methods}

The main method used for this study is a thematic analysis of key stakeholder interviews. The study also includes review of municipal documents and local media articles. The approach to thematic analysis of interviews follows the processes described by Braun and Clarke (2006) and Guest et al. (2014). This approach seeks to identify patterns of responses or meaning within qualitative data (Braun \& Clarke, 2006). Documents were reviewed for a description of the new regulatory regimes and contemporary public discourse. Altogether 388 media pieces were identified in a Factiva search over the years 2012 to 2019 with the keywords "ride -hailing" or "rideshare." These keywords were selected so as to not focus on the main market entrant, Uber, and maintain a wider lens. However, this is a limitation of the study given that Uber did and continues to dominate amongst ride-hailing platforms; using the company name as a keyword may have yielded more articles. These articles were read to identify common local themes and events that contributed to the public discourse. Another 71 pieces published by the municipalities were also reviewed including legislation, reports, and presentations. The document and media review provided a basis for further exploration in interviews with staff and council members.

Interviews were selected as a method because they provide an effective way of learning how people understand and rationalize their world. Due to the social nature of the interview, this approach also allows both participants and interviewers to engage with the subject (Arksey \& Knight, 1999). Thus, participants in this case were both asked questions and challenged to consider alternative perspectives on the issue, exposing rationalizations that may not have been considered on their own. Interview participants were recruited from among industry observers (2); municipal representatives including staff of municipal licensing offices who are engaged in policy, management or enforcement (12); and city council members (13). Among these key informants 11 of 12 staff were involved in the development of the new regulations, one had come to the department since the change in by-laws. Six were involved with handling industry disputes that were brought to the municipality. In total, 27 interviews were conducted representing 10 of the 13 municipalities with regulations of ride-hailing regulations and one municipality studying a change in by-laws. No participants could be secured in the municipalities of Barrie, Whitby, or Milton.

Semi-structured interviews allowed for a consistent set of questions but also the freedom to follow up on novel concepts and views raised by participants. Interviews lasted approximately 50 minutes with staff and 30 minutes with council members. All interviews were recorded, transcribed, and coded by 


\section{Municipal regulation of ride-hailing platforms in Toronto and the Greater Golden Horseshoe}

theme and subject matter. N-Vivo software, which has tools for the qualitative analysis of transcript data, was used to code the data. At the initial stages interview transcripts were reviewed and coded based on categories derived from the literature and document review. These categories were then revised as a result of themes that emerged throughout the coding process. Transcripts were reviewed on multiple occasions as well as through a series of N-Vivo keyword queries. Codes were then re-examined as new themes were identified or reconceptualized (Ignatow \& Mihalcea, 2017). To ensure internally valid results, these themes were cross-referenced ("triangulated") with evidence from documents and interviews with drivers (Guest et al., 2014). Validity was also found by exploring exceptional cases where there were a number of unique policies in use (Guest et al., 2014). Over repeated examinations, representative quotations were selected to describe these perspectives and patterns. These themes are reported along with the frequency of similar statements from other participants to demonstrate how common the views are and to provide context.

\section{Local Regulatory Regimes and Policy Agenda}

The local regulatory regimes that have developed for ride-hailing platforms across the GGH region are consistent across the majority of the municipalities, with distinct approaches to regulation only in the largest, densest city and smallest most dispersed municipalities (see Table 2). The QQE framework remains foundational for taxi regulation in the region, and many aspects remain institutionalized within contemporary taxi regulation, albeit revised and challenged in some instances. However, it is outside the scope here to fully address taxi reforms. Here we focus on how municipalities have conceived and developed the capacity and authority to intervene in the new regulatory regime applied to ride-hailing platforms specifically. This includes an examination of how municipal regulators have distinguished this emerging regime from the $\mathrm{QQE}$ regime; how this regulation has been framed with respect to on-going policy interests, and how tools of regulation have been developed even as public-sector authority has been allowed to whither.

\section{Ride-Hailing as Private Industry, Not Public} Service?

Interviews with municipal representatives overwhelmingly reveal an approach to regulation of private industry rather than provision of a public service. As one staff person explained, "whenever we undertake a regulatory exercise and we design policy, our main objectives as a municipal regulator are always consumer protection, health and safety, and nuisance control" (Municipal Staff \#4). This is the approach taken with local commercial service, such as restaurants. And while participants acknowledged "broad powers" for municipalities to intervene in ride-hailing, 21 of 25 participants prioritized a private industry model to conceptualize service delivery. In fact, the restaurant industry was the most commonly cited precedent. Restaurants are regulated to ensure food safety but menu items and meal pricing remain at the discretion of individual businesses. Similarly, for the ride-hailing industry, "are they [the drivers] insured? Are the vehicles inspected? Those are the types of baseline [considerations] that we need to have to ensure consumer safety. Anything beyond that, I don't think needs to be our concern at all" (Councillor \#5). A description of the common tenets of vehiclefor-hire regulations across the GGH region are shown in Table 2.

The comparison to the restaurant industry aligns with a discourse in favour of ride-hailing deregulation. It invokes an image of an entirely private service and scaled back municipal control over the ride-hailing industry, such as over fares or numbers of drivers. Platforms are encouraged to adapt business practices as they wish to meet minimum standards while serving their customers. At the same time, this framework does not fit the contours of the ride-hailing platform industry seamlessly either. Whereas restaurants operate with significant competition among both small and large operators and at many different price points and among myriad cuisines, there are relatively few ride 


\section{Municipal regulation of ride-hailing platforms in Toronto and the Greater Golden Horseshoe}

-hailing platforms. Drivers are required to work under the supervision of a platform. In some ways, this would be akin to demanding restaurants join a franchised chain business. Furthermore, availability and pricing of mobility services have deep equity implications that don't exist in the restaurant industry; and there are important externalities to ride-hailing platform operations that have an impact on other city services such as changes to transit ridership and the congestion of city-maintained transportation infrastructure (Clewlow \& Mishra, 2017; Erhardt et al., 2019; Henao \& Marshall, 2019;).

However, a number of participants (representing 6 of 11 municipalities examined in this study) also referenced public interests such as the long-term sustainability of the service that point to the perception of the service as a public service. This framing of for-hire vehicles as a typical local service industry rather than a public service operates in the context of continuing QQE for taxis. As one municipal staff person described, "if you look at the TNC model, they're not necessarily in a position to serve some of that market the way they're currently constituted. Taxis are" (Municipal Staff \#2). Councillors echoed this description, calling taxis an important "fall back service" where continued regulation would be required moving forward (Councillor \#3). While liberalization of taxis has taken place in some municipalities, regulation across the region has continued to protect that industry by preserving street hail markets for taxi exclusively. However, as street hailing continues to fall in comparison to digital requests for service, the changes undermine the economics of the taxi service, potentially creating a condition where it ceases to operate. Yet platforms are not generally deemed able to provide the same level of service as taxis, effectively applying deregulation across the entire market.

\section{Authority and Capability Behind Regulation}

Changes to the local regulatory system were highly reactive, driven by the arrival of platforms to the municipality. The pressure to change was expressed by interviewees as a lack of authority and capacity to regulate new industry actors in the same manner that municipalities had done previously through the QQE regime. A number of councillors (5 of 13) suggested that municipalities may not have the capability to regulate; whereas, municipal staff were far more confident that regulation could work. However, at the same time, several staff ( 3 of 12) noted that regulation worked only because municipalities had voluntarily accepted the standards of service preferred by the platforms. While municipalities in the GGH region have the authority to regulate prices and numbers of drivers, participants suggested that their focus ought to be only on safety regulations. This view was particularly common among staff. Ten of 12 staff interviewees felt only safety regulations were appropriate. These findings again point to a shift in local regulatory regime from one previously characterized as private delivery of a public service to a private service altogether.

The previous local regulatory regime allowed for direct inspections of cars by municipal mechanics, the collection of driver credentials by municipal staff, and the provision of a quasi-judicial system for resolving complaints for customers, taxi companies and individually regulated drivers. Under the new system much of that has been devolved to the private sector to administer including background checks, vehicle inspections and the resolution of complaints. Vehicle inspections by municipalities may still take place but are likely superficial - conducted by an officer without expertise as a vehicle mechanic (see Figure 2). A similar pattern exists regarding complaints. Five of six of the staff interviewed, who were in the position of fielding complaints, remarked that they heard very few complaints regarding ride-hailing platforms. As one municipal staff person explained:

"Let's say that someone gets into an Uber car and they are not satisfied, they report that to Uber. They don't necessarily, and I would say $95 \%$ or higher, don't report that to us... So, we get complaints. We generally field them back and work in conjunction with the [ridehailing platform] company itself. And I hate 
Municipal regulation of ride-hailing platforms in Toronto and the Greater Golden Horseshoe

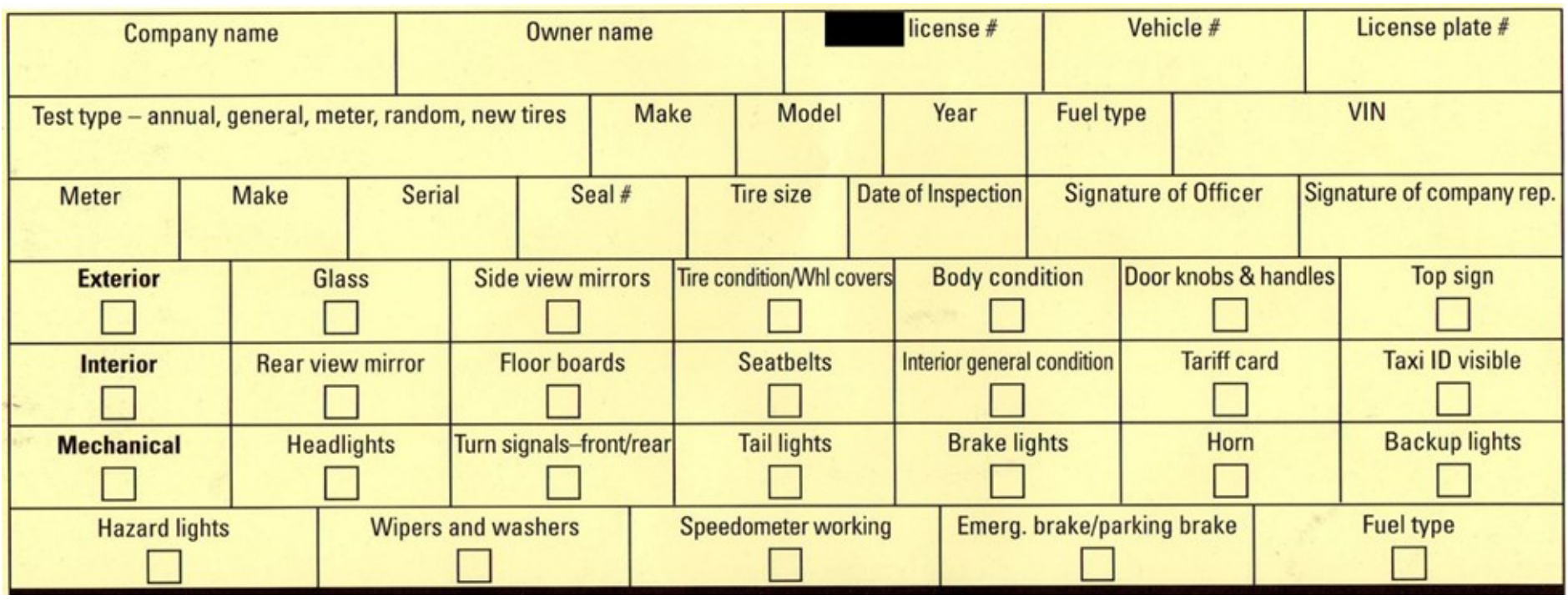

Figure 2. In-field vehicle inspection form from one municipality.

to use the term, I don't like the term, 'selfregulating'... but from an enforcement perspective it takes a burden off of us" (Municipal Staff \#9).

Interview participants also expressed enthusiasm about having more control over workers as a result of cooperating with platforms because, "if a vehicle is found not to be safe, it's removed immediately [by the platform]" (Municipal Staff \#12). Ridehailing platforms face none of the delays associated with municipal hearings that are common for the regulation of taxis and that staff described as "time consuming" (Municipal Staff \#9). Reducing this burden is all the more useful for staff members as the number of complaints was identified by councillors as a key metric by which the by-law should be judged (Councillor \#7). This contrasts with the exasperation several participants expressed regarding the previous regime. As one staff person noted, taxis had long been a "regulatory nightmare" (Municipal Staff \#6). "One thing you will learn," another council member stated, "is that any councillor that has had to deal with taxis hates it because it's always awful and it always takes forever" (Councillor \#2).

The changing dynamic of perceived authority and capacity is resolved in the new regime as a form of collaboration between municipal regulators and ride -hailing platforms. Platforms themselves are subject to comparably few controls over how they operate. Municipalities retain only a blunt tool whereby they can withdraw a license or fail to renew a license should a platform be found not to be "acting with honesty and integrity" (Municipal Staff \#8). One council member that was active in the development of for-hire vehicle regulations was circumspect about the capacity of municipalities to address municipal goals under the new framework. "I mean we have a document that says that we can license [ride-hailing platforms] but the license is effectively meaningless. It has no meaningful restrictions. You keep the principle that we are allowed to license in exchange for giving away the value of licensing" (Councillor \#2).

The regulation of for-hire vehicles, it would seem, has settled into a system of control over workers without an equivalent democratic oversight upon the service broadly. Where there is oversight, it is framed by a private system that lacks the contractual or employment agreements that can provide municipalities with clear and predictable outcomes. This was not lost on councillors, 6 of 13 of whom expressed a lack of confidence in the regime to control the industry. Further, a 2019 legal decision in Ontario now moving to the Supreme Court reached the conclusion that drivers are equivalent to customers due to the lack in market power and, 


\section{Municipal regulation of ride-hailing platforms in Toronto and the Greater Golden Horseshoe}

therefore, should be protected in legislation (Doorey, 2019). Given the need to set municipal regulation on solid footing there is good reason to focus more resources on regulating platforms, including as a way to protect drivers.

\section{On-going Policy Concerns}

In the GGH region there are signs that mobilization is occurring around ride-hailing services and that municipalities are responding with policy changes. Safety concerns from high profile fatalities as a result of poor driver training has been a mobilizing story within the GGH region and this has resulted in new policies (Pelley, 2018). Changes to the City of Toronto's policies as a result of this mobilization include a requirement for worker training. Such a change recognizes that workers are not simply subjects to be controlled but key actors in the system that require support. Such a view is more consistent with the definition of vehicle-for-hire services as a public service linked through public mobilization. Policy issues that are less easy to understand or are outside of the topic of safety and require a more fundamental change in policy may be more difficult subjects for change. This includes topics such as price and market competition that are clearly within the authority of municipal regulation in the GGH region as per the Municipal Code (2001).

A lack of competition was highlighted by municipal representatives as a great risk to the service. In order to maintain high quality and accessible services, municipal staff were most supportive of rules that encouraged competition. This was frequently pursued with a graduated scale of fees, with lower fees for small platforms, and a policy of limiting regulation to invite market participation. And yet, even in a liberalized marketplace competition continues to be limited. Of 32 drivers interviewed for this research, none operated on a platform other than Uber or Lyft and many did not even know the names of other competitors.

There is also evidence that liberalization has not preserved the public interest in important niche areas, such as services for individuals with disabilities (New York Lawyers for Public Interest, 2018). Accessible vehicle-for-hire services require more significant upfront investments from local car owners for a smaller overall market. Regulation in the City of Toronto has demanded that the large platforms $(500+$ drivers $)$ provide accessible services, which led to an additional subsidy from platforms to drivers for wheelchair accessible services. In other municipalities there are additional fees placed on platforms that are then allocated in grants to pay for wheelchair accessible vehicles among other firms. There is conflicting evidence as to whether wait times have improved for accessible transportation in Toronto (City of Toronto, 2019; Young \& Farber, 2020). However, a review of the multi-year plans of ten major Ontario municipalities "confirmed that none appeared to show a guaranteed proportion of accessible taxicabs, or appeared to provide any details with respect to progress toward determining a goal proportion" (Transportation Standards Development Committee, 2018).

Concerns about the price of rides is another question that will be difficult to mobilize around as platforms continue to subsidize rides (Calo \& Rosenblat, 2017). Currently, ride-hailing platforms Uber and Lyft subsidize rides in order to gain market share and retain drivers. This is often not considered a form of price fixing as consumers are supported with lower prices (Khan, 2016). Yet, scholars warn that rising prices and further discriminatory pricing should be expected in the future if platforms continue to gain market share and platforms are more empowered to leverage their pricing power (Horan, 2015). It is at this point, scholars argue that platforms can best leverage asymmetries of information with users and discriminatory pricing (Calo \& Rosenblat, 2017). With platforms typically tying prices to a range of undisclosed variables, including personal details about the customer rather than the costs of production (Newcomer, 2017), there are clear mechanisms for rides to be priced as a luxury good rather than a basic service or subsidized for a particularly valuable class of rider. This upends historical goals for the industry that prioritized a viable basic service and portends to 


\section{Municipal regulation of ride-hailing platforms in Toronto and the Greater Golden Horseshoe}

reduce mobility for low income and disabled individuals who are common users of these services (Ellis, 2016; King \& Saldarriaga, 2017). Given that the ridership of ride-hailing applications tend to be young and wealthy, the lack of suitability to low income users is a legitimate challenge (Young \& Farber, 2019).

The majority of municipal representatives showed little concern about the potential for price discrimination (20 of 25 participants). Participants did note that "a big component in the bylaw [is] where the passenger has to accept the price of the ride before the ride is confirmed" (Municipal Staff \#8). But when confronted with questions about the fairness of the system considering extreme information asymmetries between platforms and platform users, municipal staff were indifferent. "Consumers are not naïve," one staff person reasoned. "They know that they can see what the Uber price is and they can also pull up the [local taxi competitor]" (Municipal Staff \#12). As another staff person argued, "it's buyer beware." $\mathrm{He}$ continued that data extraction is "just good business" (Municipal Staff \#1). Other staff were swayed by the benefits of data collection for municipalities regardless of the effects for residents. Staff described using data from ride-hailing platform to target enforcement in oversight of drivers. Another staff person stated that "we are appreciative of Uber doing that screening and that checking of their drivers. From what we're aware of, it's pretty rigorous surveillance of drivers that operate on the platform. Such as, if they are holding their phone when they are driving, that is something that is detected" (Municipal Staff \#5).

The support for ride-hailing platform operations without the commensurate oversight of these platforms by democratic institutions suggests that municipal regulators favour market-based solutions. At the same time, our evidence suggests that these same municipal regulators are willing to overlook the negative externalities that exist and remain reluctant to regulate the ride-hailing industry. This market-based approach to the for-hire vehicle industry stands in the way of growing regulatory powers over the ride-hailing platforms themselves.

\section{Building Tools of Platform Governance}

The greatest policy adaptation from municipal regulators has been to withdraw direct control over drivers (municipal vehicle inspections, municipal background checks). Instead, regulators are beginning to manage drivers through random sampling whereby only a selection of drivers is inspected over the year. Interviewees argue that this approach should be just enough to have drivers comply (Municipal Staff \#6) but arguably it leaves municipalities with a real weakness. The focus on individual strategies leaves only vague threats against platforms themselves; and it is the platform that most clearly directs the operations of the industry by determining the costs of the ride, screening drivers, and distributing rides across the platform (Van den Steenhoven, 2017).

Municipal staff showed confidence in their capacity to expand regulatory oversight and participants described some novel programs, which we discuss below. Participants argued that they could secure a budget for greater regulatory measures. For instance, municipalities currently gather fees ranging from $\$ 0.08$ to $\$ 0.30$ per ride. These modest fees leave room to raise budgets before these fees become onerous. At the same time, attempts by Ontario municipalities to regulate the platform have been met with resistance. The City of Toronto was rebuffed by provincial courts after an attempt to ban the Uber platform before developing a new set of regulations. In smaller municipalities there is the risk that platforms may determine that it is not worth meeting local regulations and withdraw from the municipality instead. This was the case in the City of Orillia. Regulations in that town requiring drivers to get a vulnerable sector check were opposed by Uber and it abruptly pulled out of the municipality (Dawson, 2018).

For municipalities where there is a risk of platforms simply withdrawing from the jurisdiction, a strategy that may help expand the perceived authority of municipalities is to subsidize ride-hailing services 


\section{Municipal regulation of ride-hailing platforms in Toronto and the Greater Golden Horseshoe}

through municipal budgets as a form of transit. In the Town of Innisfil, direct subsidies for individual rides - particularly at locations of significant public value - have enabled greater service and a level of municipal oversight tied to contractual agreement between the town and the ride-hailing platform. As a town service there have been numerous additions made to the service to ensure accessibility such as the provision of telephone call-based services through the town hall. Such an approach acknowledges the public value of for-hire vehicle services yet places a financial and administrative burden on the municipality. The use of direct subsidies is particularly important given that vehicle -for-hire service does not benefit from the economies of scale that are typical of transit operations. Thus, as the system expands, the budget for these services could be difficult to contain. Indeed, Innisfil has had to curtail service to maintain budget controls. However, there would seem to be numerous contractual tools for municipalities to build authority and to ensure highquality and accessible services including the demand for unionized and trained staff, or transparency regarding the variables that determine pricing. Other municipalities in the GGH have examined ride-hailing services as an option for public transportation particularly in other small urban centers looking for greater levels of service in the evenings or for classes of resident with higher service needs.

Another potential strategy for expanding intervention in the vehicle-for-hire industry requires a more collaborative approach to regulation across levels of government. Municipal representatives noted that they "are only one player in the regulation game" (Municipal Staff \#7). To integrate for-hire vehicles with transit policy there is a need to pursue both proactive municipal programs with reactive regulation, which requires coordination between municipal agencies and departments. In the GGH region, transit policy is largely regulated among upper-tier municipalities while for-hirevehicle services is regulated mostly by lower-tier municipalities. In other policy areas this exists as well. Policy areas like pricing and competition are now subject to industry dynamics like anti-trust and data protection that are the jurisdiction of senior levels of government. While few participants called for provincial intervention into the industry, there is good reason to see collaboration between governments as a means to integrate resident interests into robust regional economic and infrastructural systems through provincial legislative power. The GGH region already has a regional transportation agency called Metrolinx that could be applied to this service.

For municipalities in less risk of full platform withdrawal, direct regulations of platform software and algorithms shows promise. For instance, in the effort to ensure that platforms are communicating prices to passengers clearly before the ride, the City of Toronto has required approval of the platform graphic interface (Municipal Staff \#7). For other policy issues oversight requires more data to be supplied to the municipality. Municipal staff noted that demanding more data is well within the rights of the municipality, stating that "we can demand all types of data, if there's a justified reason for it" (Municipal Staff \#4). The City of Toronto has a data sharing agreement that collects raw data from the platform within a number of fields including the origin and destination of trips and details about the driver. A couple municipalities ( 2 of 9 municipalities where staff were interviewed) reported having a data scientist on staff or in a consulting position to help monitor data reports from the ride-hailing platforms. There may also be an emerging industry for "compliance monitoring service $[\mathrm{s}], \ldots$ where if our municipality has got a licensing system... they have got an algorithm that can... provide you with the information for enforcement" (Municipal Staff \#4). Indeed, one staff member from a rural municipality reported that "we have been approached by... universities to assist with analyzing the data as well. So that's something that may happen in the near future" (Municipal Staff \#5). 
CONClusions: Defining a Role For Local REgULATION

The aim of this paper is to understand how municipal representatives make sense of their role in regulating the vehicle-for-hire industry and how policy has developed as a result. For-hire vehicle services are considered both a private industry and public service and municipalities have long regulated the industry to ensure an affordable and accessible service is offered. With the rise of ridehailing platforms, there has been a move to liberalize the service, to remove democratic control over characteristics such as price and competition, and instead place the service entirely within a private market setting. While others have documented how this may be attributed to industry lobbying and pro-business policies among higher levels of government (Collier et al., 2018), this case study demonstrates incentives at the municipal scale for greater liberalization as well. The case also shows, however, that liberalization is leading to further externalities being placed on the public and on drivers.

The findings suggest that to maintain basic transportation services, municipalities should build tools of oversight and fully recognize their existing authority to control vehicle-for-hire markets for multiple public interests. To do so demands expanding regulatory oversight of platforms and not only individual drivers. Through flexible interventions municipalities may create more robust systems to address the public interest. Like other areas of infrastructure previously characterized by a desire for a homogeneous level of service, a new balance of interests must now be established in the ride-hailing industry.

We have suggested that regulation should place a greater focus on oversight of platforms in order to meet the diverse public interests of residents and drivers. The mix of private delivery and public service is common in infrastructure markets where public mobilization has placed demands on providers to balance public and private values. To develop democratic oversight and balance diverse interests, municipalities must recognize the benefit and value of municipal regulation and reassert the capacity and authority with which they are already equipped.

\section{ACKNOWLEDGMENTS}

We thank the editor, Dr. David Gordon, and three anonymous reviewers whose in-depth reading and comments greatly improved the paper. We would also like to thank Dr. Zach Spicer and participants at the 2019 annual meeting of the Creating Digital Opportunities SSHRC Partnership Grant who provided feedback on an early version of this paper. Special thanks for funding from the Ontario Graduate Scholarship that supported this research. Finally, we are grateful to the drivers, industry watchers, municipal staff and council members for their time and insights that informed this research.

\section{NOTES ON CONTRIBUTORS}

Jonathan Woodside is a $\mathrm{PhD}$ Candidate at the School of Planning at the University of Waterloo.

Dr. Markus Moos is Associate Professor in the School of Planning, Faculty of Environment at the University of Waterloo. He is also a Registered Professional Planner and member of the Canadian Institute of Planners.

Dr. Tara Vinodrai is Associate Professor in the Institute for Management and Innovation at the University of Toronto. She holds a graduate appointment to the Department of Geography and Planning and is a Senior Associate at the Innovation Policy Lab at the Munk School of Global Affairs and Public Policy.

\section{CORRESPONDING AUTHOR}

Jonathan Woodside (iD

School of Planning, University of Waterloo Email: j3woodsi@uwaterloo.ca 


\section{Municipal regulation of ride-hailing platforms in Toronto and the Greater Golden Horseshoe}

\section{REFERENCES}

Arksey, H., \& Knight, P. T. (1999). Triangulation in data collection. In H. Arksey \& P. T. Knight (Eds.), Interviewing for social scientists: An introductory resource with examples. London, UK: SAGE.

Association of Municipalities Ontario. (2020). Municipal 101| AMO.

Attoh, K., Wells, K., \& Cullen, D. (2019). "We're building their data": Labor, alienation, and idiocy in the smart city. Environment and Planning D: Society and Space, 37(6), 1007-1024. https://doi.org/10.1177/0263775819856626

Blasi, G., \& Leavitt, J. (2006). Driving poor: Taxi drivers and the regulation of the taxi industry in Los Angeles. University of California.

Bokányi, E., \& Hannák, A. (2020). Understanding Inequalities in Ride-Hailing Services Through Simulations. Scientific Reports, 10(1), 6500. https://doi.org/10.1038/s41598-02063171-9

Brail, S. (2018). From Renegade to Regulated: The Digital Platform Economy, Ride-hailing and the Case of Toronto. Canadian Journal of Urban Research, 27(2), 51-63.

Braun, V., \& Clarke, V. (2006). Using thematic analysis in psychology. Qualitative Research in Psychology, 3(2), 77101. https://doi.org/10.1191/1478088706qp063oa

Brenner, N., \& Theodore, N. (2002). Cities and the Geographies of "Actually Existing Neoliberalism." Antipode, 34(3), 349-379. https://doi.org/10.1111/1467$\underline{8330.00246}$

Calo, R., \& Rosenblat, A. (2017). The Taking Economy: Uber, Information, and Power. SSRN Electronic Journal. https:// doi.org/10.2139/ssrn.2929643

Chen, A., Yuan, C.-W., Ma, N. F., Hsu, C.-Y., \& Hanrahan, B. V. (2019). Navigating Ride-Sharing Regulations: How Regulations Changed the "Gig" of Ride-Sharing for Drivers in Taiwan. Proceedings of the 2019 CHI Conference on Human Factors in Computing Systems, 112. Glasgow Scotland Uk: ACM. https:// doi.org/10.1145/3290605.3300366

Chen, L., Mislove, A., \& Wilson, C. (2015). Peeking Beneath the Hood of Uber. Proceedings of the 2015 Internet Measurement Conference, 495-508. Tokyo Japan: ACM. https://doi.org/10.1145/2815675.2815681

City of Toronto. (2019). Review of the City of Toronto Municipal Code Chapter 546, Licensing of Vehicles-forHire, Attachment 3: Accessibility Strategy Research and Consultation Summary, Report GL6.31 Revised.

Clewlow, R. R., \& Mishra, G. S. (2017). Disruptive Transportation: The Adoption, Utilization, and Impacts of Ride-Hailing in the United States. Davis: Institute of Transportation Studies, University of California Davis,

\section{UCD-ITS-RR-17-07}

Collier, R. B., Dubal, V. B., \& Carter, C. L. (2018). Disrupting Regulation, Regulating Disruption: The Politics of Uber in the United States. Perspectives on Politics, 16(4), 919-937. https://doi.org/10.1017/S1537592718001093

Cooper, J., Mundy, R., \& Nelson, J. (2010). Taxi!: Urban economies and the social and transport impacts of the taxicab. Surrey: Ashgate Publishing Ltd.

Davis, J. (2015). Drive at Your Own Risk: Uber Violates Unfair Competition Laws by Misleading Uberx Drivers about Their Insurance Covergae. Boston College Law Review, 56(3), 1097-1142.

Dawson, D. (2018, July 20). Orillia Uber drivers will face vulnerable sector screening.

Dempsey, P. S. (1996). Taxi Industry Regulation, Deregulation, and Reregulation: The Paradox of Market Failure. Transportation Law Journal, 24, 73-120.

Doorey, D. (2019). Heller v. Uber: Supreme Court Must Guard Access to Class Action Lawsuits.

Dubal, V. B. (2017). The Drive to Precarity: A Political History of Work, Regulation, \& Labor Advocacy in San Francisco's Taxi \& Uber Economies. Berkeley Journal of Employment and Labor Law, 38(1), 73-135.

DuPuis, N., Langan, T., McFarland, C., Panettieri, A., \& Rainwater, B. (2018). City Rights in an Era of Preemption: A State-by-State Analysis. National League of Cities, Center for City Solutions.

Dupuy, G. (2008). Urban Networks: Network Urbanism. Techne Press.

Ellis, E. H. (2016). Use of Taxis in Public Transportation for People with Disabilities and Older Adults (p. 24628). Washington, D.C.: Transportation Research Board. https:// doi.org/10.17226/24628

Erhardt, G. D., Roy, S., Cooper, D., Sana, B., Chen, M., \& Castiglione, J. (2019). Do transportation network companies decrease or increase congestion? Science Advances, 5(5), eaau2670. https://doi.org/10.1126/ sciadv.aau 2670

Farrell, D., Greig, F., \& Hamoudi, A. (2018). The Online Platform Economy in 2018: Drivers, Workers, Sellers, and Lessors. New York: JP Morgan Chase Institute.

Ferreri, M., \& Sanyal, R. (2018). Platform economies and urban planning: Airbnb and regulated deregulation in London. Urban Studies, 55(15), 3353-3368. https:// doi.org/10.1177/0042098017751982

Geobey, S. (2017). Planning for the sharing economy. In M. Moos, D. Pfeiffer, \& T. Vinodrai (Eds.), The Millennial City Trends, Implications, and Prospects for Urban Planning and Policy (pp. 93-106). Routledge. 


\section{Municipal regulation of ride-hailing platforms in Toronto and the Greater Golden Horseshoe}

Graham, S., \& Marvin, S. (2001). Splintering urbanism networked infrastructures, technological mobilities and the urban condition. London: Routledge.

Griswold, A. (2018, September 13). Uber drivers are forcing riders to cancel trips when fares are too cheap. Quartz.

Guest, G., MacQueen, K. M., \& Namey, E. E. (2014). Applied thematic analysis. Los Angeles, Calif.; London: Sage.

Guse, C. (2019, April 17). Uber and Lyft continue rapid growth in NYC despite regulations. New York Daily News.

Hackworth, J. R. (2013). The neoliberal city: Governance, ideology, and development in American urbanism. Ithaca, NY: Cornell University Press.

Harding, S., Kandlikar, M., \& Gulati, S. (2016). Taxi apps, regulation, and the market for taxi journeys. TRA Transportation Research Part A, 88, 15-25.

Henao, A., \& Marshall, W. E. (2019). The impact of ridehailing on vehicle miles traveled. Transportation, 46(6), 2173-2194. http://dx.doi.org/10.1007\%2Fs11116-0149531-8

Horan, H. (2017). Will the Growth of Uber Increase Economic Welfare. Transportation Law Journal, 44(1), 33-105.

Hua, J., \& Ray, K. (2018). Beyond the precariat: Race, gender, and labor in the taxi and Uber economy. Social Identities, 24(2), 271-289. https:// doi.org/10.1080/13504630.2017.1321721

Ignatow, G., \& Mihalcea, R. (2017). Thematic Analysis, Qualitative Data Analysis Software, and Visualization. In Text mining: A guidebook for the social sciences. Sage Publications.

Jalali, R., Koohi-Fayegh, S., El-Khatib, K., Hoornweg, D., \& Li, H. (2017). Investigating the Potential of Ridesharing to Reduce Vehicle Emissions. Urban Planning, 2(2), 26-40. https://doi.org/10.17645/up.v2i2.937

Johnston, H. (2018). Workplace Gains beyond the Wagner Act: The New York Taxi Workers Alliance and Participation in Administrative Rulemaking. Labor Studies Journal, 43(2), 141-165. https:// doi.org/10.1177/0160449X17747397

Kenney, M., \& Zysman, J. (2016). The Rise of the Platform Economy. Issues in Science and Technology, 32(3), 61-69.

Khan, L. M. (2016). Amazon's Antitrust Paradox. Yale Law Journal, 126(3), 710-805.

Kim, J., \& Hwang, J. (2019). The Future of Local Governance for Appropriately Adapting the Ride-Sharing Platform: Case Study of Seoul, New York, and Maryland. Presented at the Workshop on the Ostrom Workshop (WOW6), Indiana University Bloomington.

King, D., \& Saldarriaga, J. (2017). Access to Taxicabs for
Unbanked Households: An Exploratory Analysis in New York City. Journal of Public Transportation, 20(1), 1-19. https://doi.org/10.5038/2375-0901.20.1.1

Ministry of Municipal Affairs and Housing. (2020). A Place to Grow Growth Plan for the Greater Golden Horseshoe.

Mishel, L. (2018, May 15). Uber and the labor market: Uber drivers' compensation, wages, and the scale of Uber and the gig economy.

Mitchell, M. D., \& Koopman, C. (2018). Taxis, Taxis, and Governance in the Vehicle-For-Hire Industry. In N. M. Davidson, M. Finck, \& J. J. Infranca (Eds.), The Cambridge handbook of law of the sharing economy. Cambridge, UK: Cambridge University Press.

New York Lawyers for Public Interest [NYLPI]. (2018). Left Behind: New York's For-Hire Vehicle Industry Continues to Exclude People with Disabilities. New York, NY.

Newcomer, E. (2017, May 19). Uber Starts Charging What It Thinks You're Willing to Pay. Bloomberg.com.

NYC Taxi \& Limousine Commission. (2018). 2018 TLC Fact Book.

Papillon, B.-M. (1982). The Taxi Industry and Its Regulation in Can. Working Paper. Presented at the No. 30. Economic Council of Canada.

Peck, J., \& Tickell, A. (2002). Neoliberalizing Space. Antipode, 34(3), 380-404. https://doi.org/10.1111/14678330.00247,

Pelley, L. (2018, October 5). 20,000 people are calling on city council to bring back training for taxi, ride-sharing drivers | CBC News. $\underline{\text { CBC News. }}$

Plantin, J.-C., Lagoze, C., Edwards, P. N., \& Sandvig, C. (2018). Infrastructure studies meet platform studies in the age of Google and Facebook. New Media \& Society, 20 (1), 293-310. https://doi.org/10.1177/14614448816661553

Puche, M. L. (2019). Regulation of TNCs in Latin America: The Case of Uber Regulation in Mexico City and Bogota. In M. Finger \& M. Audouin (Eds.), The Governance of Smart Transportation Systems (pp. 37-53). Cham: Springer International Publishing. https:// doi.org/10.1007/978-3-319-96526-0_3

Rayle, L., Shaheen, S., Chan, N., Dan, D., \& Cervero, R. (2016). App-Based, On-Demand Ride Services: Comparing Taxi and Ridesourcing Trips and User Characteristics in San Francisco. Transport Policy, 45(C), 168-178.

Reid-Musson, E., MacEachen, E., Bartel, E., Saunders, R., Meyer, S., \& Bigelow, P. (2020). Occupational Safety and the City: Licensing Regulation and Deregulation in the Taxi Sector. Relations industrielles, 75(1), 101. https:// doi.org/10.7202/1068717ar

Rosenblat, A. (2018). Uberland: How algorithms are rewriting Aménagement et politique au Canada 2021 
the rules of work. Oakland, CA: University of California Press.

Sancton, A. (2011). Canadian Local Government: An Urban Perspective. Oxford, UK: Oxford University Press

Scott, A. J., \& Storper, M. (2015). The Nature of Cities: The Scope and Limits of Urban Theory: The nature of cities. International Journal of Urban and Regional Research, 39 (1), 1-15. https://doi.org/10.1111/1468-2427.12134

Spicer, Z., Eidelman, G., \& Zwick, A. (2019). Patterns of Local Policy Disruption: Regulatory Responses to Uber in Ten North American Cities. Review of Policy Research, 36 (2), 146-167. https://doi.org/10.1111/ropr.12325

Srnicek, N. (2017). Platform Capitalism. Cambridge, UK: Polity Press.

Sundararajan, A. (2017). The sharing economy: The end of employment and the rise of crowd-based capitalism. Cambridge, Massachusetts: MIT Press.

Transportation Standards Development Committee. (2018, May 2). Final recommendations: 2018 Review of the Accessibility Transportation Standards.

Uber. (2021). How much does a ride with the Uber app cost?

Van den Steenhoven, J., Burale, I., Toye, V., \& Bure, C. (2016). Shifting Perspectives: Redesigning Regulation for the Sharing Economy. Ottawa, ON: MaRs Solution Lab.

Viswanathan, N. (2018). Tax Compliance and the Sharing Economy. In N. M. Davidson, M. Finck, \& J. J. Infranca (Eds.), The Cambridge handbook of law of the sharing economy (pp. 357-367). Cambridge, UK: Cambridge University Press.

Wells, K. (2019). The Uber Workplace in D.C. Washington. Washington, D.C: Georgetown University Kalmanovitz Initiative for Labor and the Working Poor.

Young, M., \& Farber, S. (2019). The who, why, and when of Uber and other ride-hailing trips: An examination of a large sample household travel survey. Transportation Research Part A: Policy and Practice, 119, 383-392. https://doi.org/10.1016/j.tra.2018.11.018

Young, M., \& Farber, S. (2020). Using Wait-time Thresholds to Improve Mobility: The Case of UberWAV Services in Toronto. Findings. https://doi.org/10.32866/001c.14547

Zale, K. (2019). Scale and the Sharing Economy. (pp. 38-50). In N.M. Davidson, M Finck, \& J. J. Infranca (Eds.), The Cambridge handbook of law of the sharing economy. Cambridge, UK: Cambridge University Press. 